\title{
Aplikasi Transformasi Curvelet untuk Denoising Random Noise : Studi Kasus Data Seismik Sintetik 2D Darat "Antiklin"
}

\author{
Diptya Mas Nugraha, Ayi Syaeful Bahri, dan Dwa D. Warnana \\ Departemen Teknik Geofisika, Fakultas Teknik Sipil dan Perencanaan, Institut Teknologi Sepuluh Nopember (ITS) \\ e-mail:dwa_desa@yahoo.co.uk
}

\begin{abstract}
Abstrak-Denoising (reduksi noise) merupakan hal umum yang dilakukan pada pengolahan data seismik. Secara umum, kita telah mengenal berbagai filter konvensional seperti bandpass filter dan metode signal enhancemet seperti F-X Deconvolution. Metode tersebut telah lama digunakan dan memiliki kelemahan yakni belum mampu mengembalikan reflektor secara maksimal dengan baik sedangkan noise memiliki nilai frekuensi yang sama dengan nilai sinyal yang baik. Pada penelitian ini, penulis menggunakan data seismik sintetik. Noise yang digunakan adalah gaussian noise karena noise ini merupakan noise yang digunakan secara umum dalam dunia statistik. Setelah ditambahkan noise, maka data sintetik akan diolah menggunakan transformasi curvelet. Hasil dari pengolahan data adalah data seismik sintetik "Antiklin" memiliki nilai signal to noise ratio (SNR) yakni antara 27 hingga 28 dB. Data seismik sintetik ketika diberikan noise memiliki nilai SNR yakni antara 19 hingga 25 dB. Dengan demikian, dapat dikatakan bahwa transformasi curvelet mampu melemahkan dan menghapus random noise. Sementara itu, reflektor pada data masih memiliki bentuk yang hampir sama dengan data forward modelling.
\end{abstract}

Kata Kunci-Denoising, Transformasi Curvelet, Signal to Noise Ratio.

\section{PENDAHULUAN}

$\mathrm{P}$ ENGOLAHAN data seismik merupakan langkah untuk memperoleh data dengan sinyal yang baik. Akuisis i data seismik yang dilakukan di lapangan kadang memberikan sinyal yang buruk sehingga menampilkan data seismik yang kurang baik. Data seismik perlu dilakukan berbagai macam filter sehingga akan mempermudah proses langkah selanjutnya. Salah satu tantangan dalam pengolahan data adalah menghilangkan sinyal buruk (noise). Noise terjadi akibat gelombang seismik yang menjalar pada bawah permukaan melewati berbagai macam perlapisan dengan nilai densitas yang bermacam-macam serta akibat gangguan angina, instrumen dan aktivitas manusia. Akibatnya, pada data seismik menghasilkan dua jenis noise yaitu noise acak dan noise koheren. Noise acak merupakan noise yang diakibatkan oleh kegiatan manusia meliputi instrumen, dan angina [1]. Noise koheren disebabkan oleh adanya kondisi geologi permukaan sehingga gelombang seakan-akan terjebak, seperti multiple, gelombang permukaan, efek ghosting, difraksi dan lain-lain.

Filter umum yang sering digunakan dalam pengolahan data seimsik yakni band pass filter, F-X Deconvolution [2] dan lain-lain merupakan metode yang menggunakan skala tunggal, yaitu pada frekuensi atau waktu. Kelemahan pada metode ini (F-X Deconvolution) adalah filter koheren yang digunakan belum tentu mampu melemahkan noise acak yang tersebar pada penampang seis mik dengan energi yang acak sehingga menyebabkan event seismik yang terlihat buatan dan membuat interpretasi menjadi tidak unik [3]. Tidak hanya itu, penggunaan teknik konvensional filter seperti F-X Deconvoluiton dan Median Filtering menghilangkan jumlah noise yang banyak namun juga membahayakan komponen sinyalnya [4] sehingga perlu suatu filter untuk memisahkan sinyal dan noise yang baik.

\section{TRANSFORMASI CURVELET}

Transformasi curvelet merupakan metode multiskala yang mampu memisahkan noise dan sinyal pada domain frekuensi, dip, posisi dan lokasi [5]. Transformasi Curvelet mampu mengestimasi data noise yang tak dikenal, dimisalkan dengan $m$, dengan persamaan sebagai berikut:

$$
y=m+n
$$

dimana $y$ adalah data noise, dan $\mathrm{n}$ adalah pusat nol noise Gaussian [6]. Tujuan utama dalam persamaan ini adalah untuk memulihkan $m$ tanpa kehilangan informasi refleksi yang koheren, sehingga $m$ diperluas di domain curvelet yaitu

$$
y=C^{h} x+n
$$

Dasar windowing yang digunakan dalam transformasi curvelet menggunakan prinsip Meyer [7] adalah sebagai berikut :

$$
\begin{array}{cc}
\sum_{j=-x}^{m}=W^{2}\left(2^{j} r\right)=1 & r>0 \\
\sum_{t=-x}=V^{2}(t-1)=1 & \text { teR }
\end{array}
$$

Pengolahan data pada Transformasi curvelet mengalami percepatan dan penambahan metode sehingga dalam proses pengolahannya dapat menghasikan image (gambar) dengan reduksi noise yang dapat ditingkatkan, sehingga dikenal sebagai fast discrete curvelet transform (FDCT) (Candes E.J., 2006). FDCT dibagi menjadi dua yaitu via Unequispaced Fast Fourier Transform dan via Wrapping. Untuk menentukan koefisien curvelet via wrapping adalah sebagai berikut :

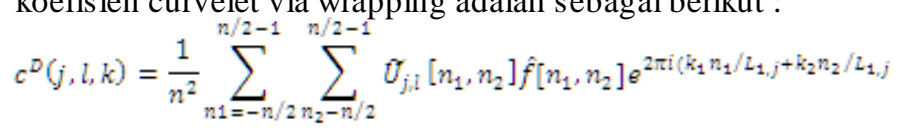

dengan $C^{D}$ merupakan koefisien curvelet pada $j$ (skala), $l$ (sudut), dan $k$ (posisi), sedangkan $U_{j}$ merupakan jendela frekuensi untuk tiap $n 1$ dan $n 2$ dan $L_{l, j} L_{2, j}$ merupakan bagian piksel pada gambar (image). Langkah-langkah pada setiap melakukan transformasi curvelet via wrapping adalah 
sebagai berikut :

- Fast Discrete Curvelet Transform(FDCT)

Pada proses ini didapatkan nilai koefisien curvelet. Pada proses tersebut terdapat beberapa langkah yang harus dilakukan yaitu :

1). Dilakukan FFT 2D (Fast Fourier Transfrom) untuk tiap pasangan skala/sudut $(j, l)$ dari tiap susunan $\varepsilon^{\mathbb{D}_{i} \mathbb{N}_{0}}\left(j_{0} \mathbb{R}_{s} k\right)$ dan didapatkan $W\left(U_{i n} f\right)\left[n_{1} n_{2}\right]$.

2) Dikalikan susunan $W\left(U_{f_{1}} f\right)\left[n_{1} n_{2}\right]$ dengan pertimbangan curvelet wrapping $W\left(U_{\pi_{1}}\right)\left[n_{1} n_{2}\right]$ yag menghasilkan

$$
W\left(\left|U_{j 1}\right|^{2} f\right)\left[n_{1} n_{2}\right]
$$

3). Unwrap susunan tiap $W\left(\left|U_{j d}\right|^{2} f\right)\left[n_{1} n_{2}\right]$ pada grid frekuensi dan ditambahkan nilai dari $W\left(\left|U_{j N}\right|^{2} f\right)\left[n_{1} n_{2}\right]$ pada tiap-tiap grid frekuensi sehingga mampu memperoleh kembali $f\left[n_{1} n_{2}\right]$.

4). Dilakukan inverse FFT 2D untuk mendapatkan $f\left[t_{1} t_{2}\right]$.

- Cycle Spinning

Proses ini dilakukan untuk meningkatkan denoising (reduksi noise) dengan proses translasi per dimensi pada sinyal dengan variasi time shift (pergeseran waktu). Pada proses ini, dilakukan Fast Discrete Curvelet Transform (FDCT) sehingga didapatkan koefisien curvelet terbaru.

- Threshold

Proses ini digunakan untuk mengurangi noise yang paling sederhana dan menjadi das ar bagi beberapa metode pengurangan noise yang lain. Threshold akan menghasilkan nilai rekonstruksi dari proses sebelumnya dengan bantuan proses Inverse Fast Discrete Curvelet Transfrom (IFDCT), dengan input dari cycle spinning .

- Iterasi Norm L1

Proses ini digunakan untuk filter noise menggunakan penyelesaian gradien konjugasi. Proses iterasi juga dilakukan FDCT untuk mendapatkan koefisien curvelet terbaru, dengan inisial 'D'. Iterasi berdasarkan pada parameter yang telah ditentukan, yaitu pada nell1.

\section{- Threshold}

Proses ini digunakan untuk mengurangi noise yang paling sederhana dan menjadi das ar bagi beberapa metode pengurangan noise yang lain. Threshold akan menghasilkan nilai rekonstruksi dari proses sebelumnya dengan bantuan proses IFDCT (Inverse Fast Discrete Curvelet Transform).

- Inverse Fast Discrete Curvelet Transform(IFDCT)

Proses ini digunakan untuk merekonstruksi ulang gambar. Tidak seperti FDCT, pada proses ini dibuka/dipecah kembali susunan data dari transformasi fourier pada setiap sudut dan skala kedalam trapezoidal. Selanjutnya, dilakukan windowing dengan indikator yang sesuai, kemudian dijumlahkan pada masing-masing sudut dan skala dan dilakukan inversi transformasi fourier [5].

kemudian, untuk menghitung nilai SNR pada data adalah sebagai berikut :

PSNR $=20 \log _{10} \frac{\text { WAX }_{i}}{\sqrt{\mathrm{WMSE}}}$

dengan $M A X_{i}$ adalah nilai maximum piksel pada data, $M S E$ merupakan nilai error yang didapat dari selisih matriks data sintetik dan data yang telah ditambahkan noise atau data setelah rekontruksi curvelet (restored) (Binh \& Khar, 2010).

Aplikasi Transformasi curvelet pada data seismik diantaranya mampu mengatenuasi noise acak pada aplikasi data post stack seismik 2D dan 3D (Neelamani, 2008), menghilangkan multiple pada data seis mik (Herrmann, 2007) dan aplikasi pada peningkatan sinyal dan reduksi noise pada data seismik 2D dan 3D [8] dan pada lingkungan subvulkanik [8]. Pada penelitian ini, penulis akan melakukan reduksi noise pada data seismik 2D sintetik "Antiklin". Noise yang digunakan merupakan noise acak gaussian dengan parameter bervariasi kemudian dilakukan analisis perbandingan SNR serta hasil filter sebelum dan setelah menggunakan transformasi curvelet.

\section{METODOLOGI PENELITIAN}

\section{A. Rancangan Penelitian}

Penelitian ini menggunakan data sintetik yang melalui tahapan pengolahan data seismik terlebih dahulu. Data yang digunakan adalah data stack dalam domain waktu. Kemudian dilakukan penambahan noise gaussian dengan variasi nilai sigma. Kemudian dilakukan transformasi curvelet sehingga menghasilkan output yakni SNR dan nilai error. Nilai SNR dari data yang ditambahkan noise akan dibandingkan dengan data rekonkstruksi curvelet kemudian dilakukan analisis kemenerusan reflektor seismik. Nilai error menunjukkan selisish nilai piksel pada data original dan data yang telah ditambahkan noise atau data yang telah direkonstruksi curvelet.

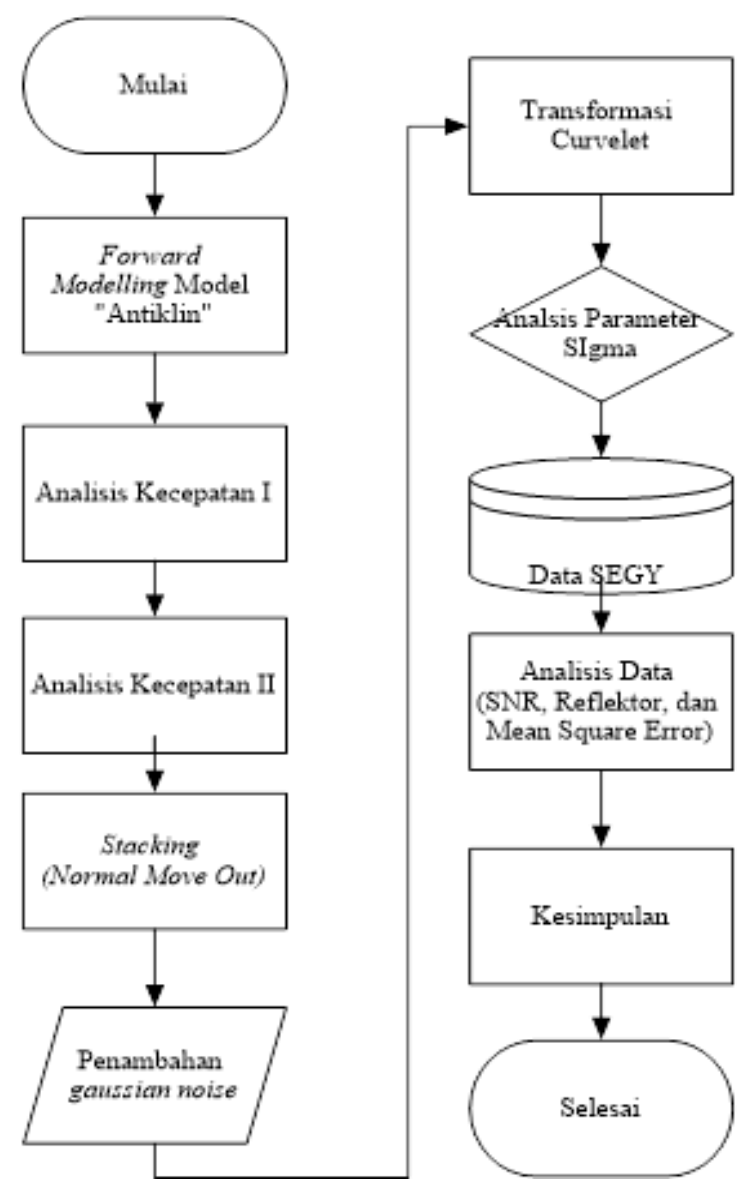

(a) 


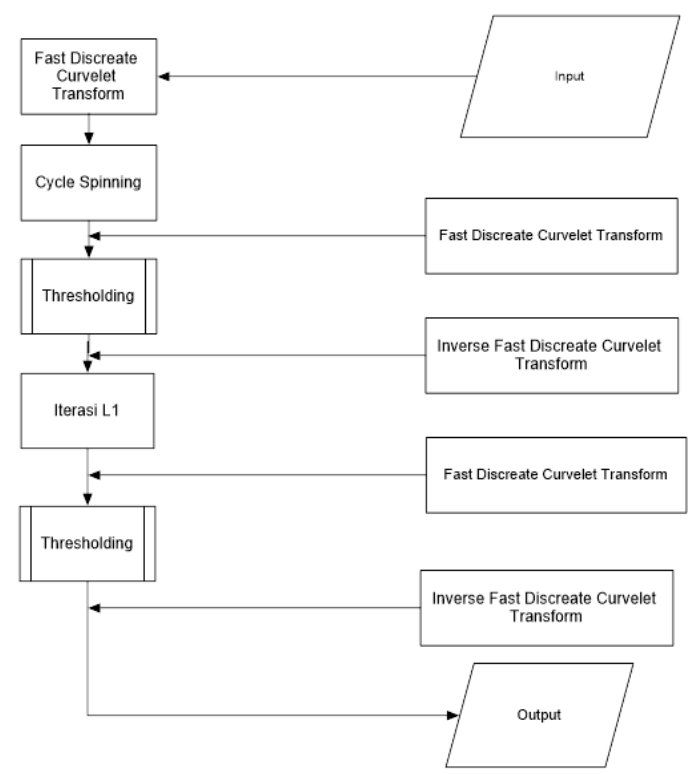

(b)

Gambar 1. Alur penelitian (a) dan langkah pengolahan data menggunakan Transformasi Curvelet (b).

\section{B. Pembuatan Model}

Model yang digunakan adalah model dengan bentuk antiklin sebagai berikut :

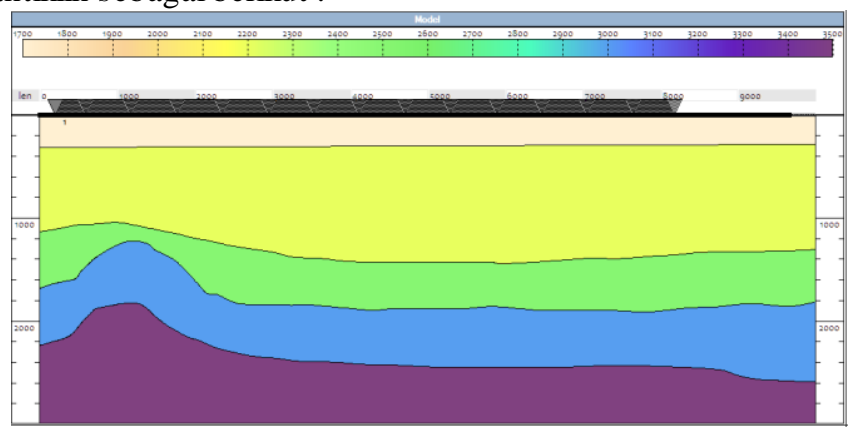

(a)

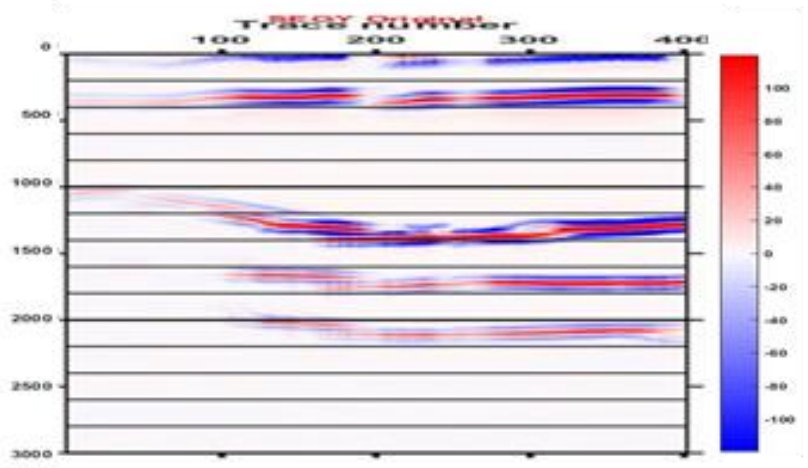

(b)

Gambar 2. Model sintetik pada tampilan software Tesseral (a) dan setelah dilakukan open data di MatLab.

Kemudian dilakukan transformasi curvelet pada data di atas dengan nilai sigma yang memengaruhi persebaran energi noise acak.

\section{Pengujian Resistivitas}

Langkah pengujian

\section{Teknik Analisis Data}

Tahap analisis

\section{HASIL DAN PEMBAHASAN}

\section{A. Hasil Data Denoising}

Dari pengolahan data seismik sintetik "Antklin" maka dihasilkan 6 data uji coba untuk atenuasi gaussian noise.

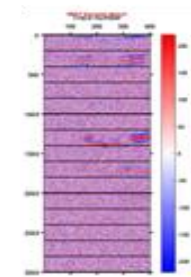

a1

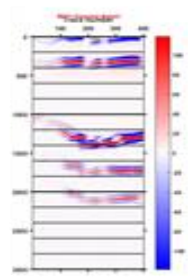

c1

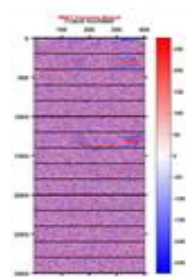

e1

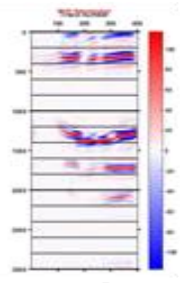

a2

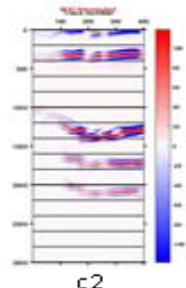

$c 2$

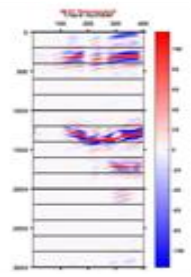

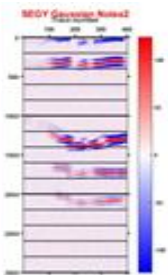

b1

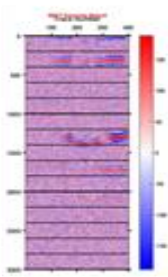

d1

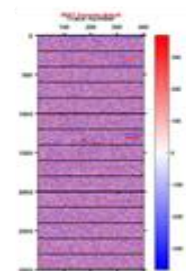

f1

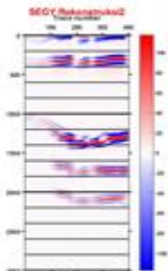

b2

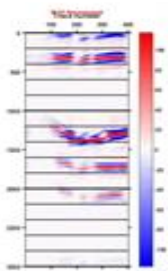

d2

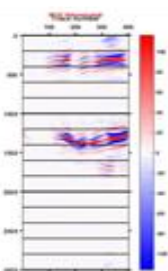

Gambar 3. Hasil percobaan dengan variasi sigma untuk noise. Bagian a1 hingga f2 secara berturut-turut merupakan data saat ditambahkan noise dan setelah transformasi curvelet.

Uji coba data pertama hingga keenam pada gambar 4 . Dilakukan secara berturut-turut yaitu dengan nilai sigma adalah 255, 25.5, 2.55, 200, 382.5, dan 510. Bagian a1 yang merupakan gambar yang telah ditambahkan noise dan a2 merupakan data setelah dilakukan reduksi noise begitu juga data b1 hingga f2. Koefisien curvelet yang dibuat pada data seismik sintetik ini dengan jumlah matriks 1000x1000 sehingga didapatkan nilai koefisien curvelet $1 \times 7$ cell. Nilai threshold yang digunakan adalah sama yaitu 2550 .

\section{B. Perubahan Nilai Signal to Noise Ratio (SNR)}

Untuk mengetahui perubahan nilai SNR pada data sebelum dan setelah transformasi curvelet maka dibuatlah grafik sebagai berikut :

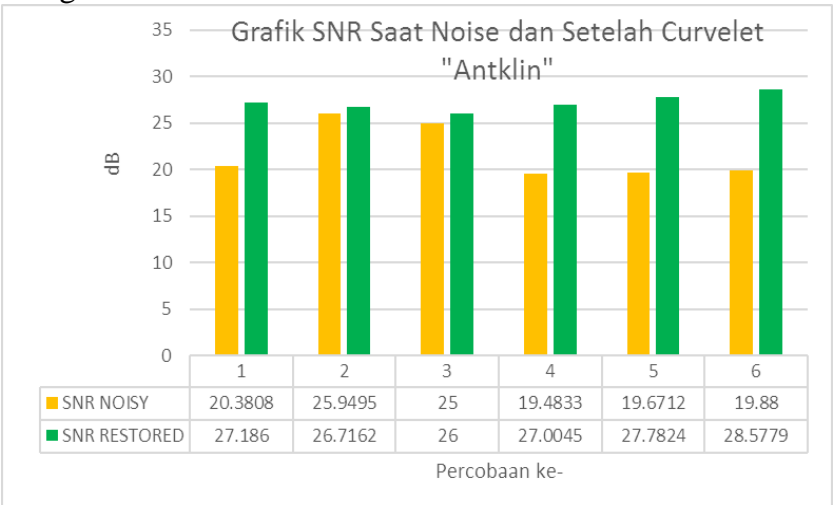

Gambar 4. Grafik Perbandingan Nilai Signal to Noise Ratio (SNR) pada data saat ditambahkan gaussian noise (warna oranye) dan setelah dilakukan transformasi curvelet (warna hijau). 

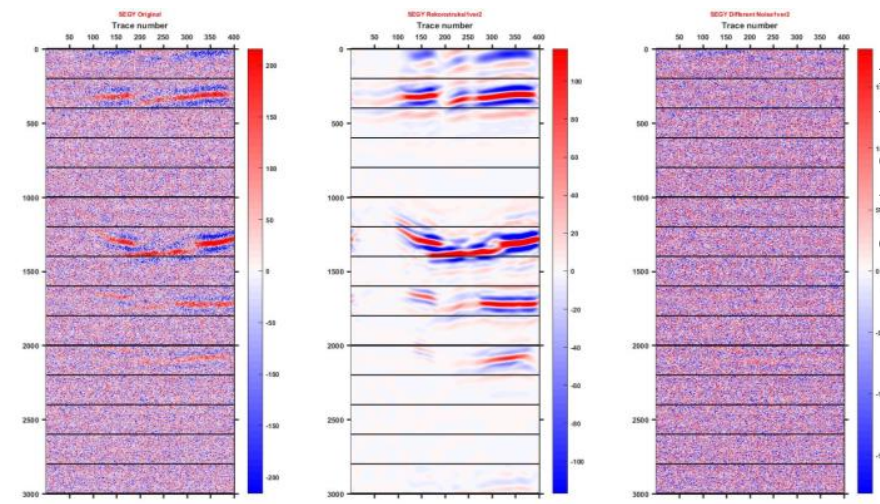

Gambar 5. Hasil transformasi curvelet pada percobaan pertama; bagian kiri merupakan data yang telah ditambahkan noise, bagian tengah merupakan hasil transformasi, dan bagian kanan merupakan perbedaan bagian kiri dan kanan.

Hasil uji coba data 1 hingga 6 menampilkan nilai SNR berdasarkan grafik di atas dengan masing-masing nilai untuk SNR noisy dan SNR restored.

\section{Pembahasan}

Berdasarkan gambar 3, atenuasi noise acak pada data sintetik bekerja cukup efektif. Hilangnya noise pada data seis mik sintetik juga menyebabkan hilangnya event seimsik sehingga kemenerusan reflektor tidak sempurna seperti data pada gambar 2 (b). Pada gambar 3, atenuasi noise dan rekonstruksi terbaik dimiliki oleh gambar a2 dan a3 dengan nilai sigma masing-masing adalah 255 dan 200. Pada data b2, penambahan noise tidak cukup kasar sehingga rekonstruksi curvelet dapat mudah dilakukan. Noise yang paling tinggi jatuh pada data f1 yaitu 510. Data f1, event seismik secara keseluruhan hampir tertutup oleh noise sehingga cukup sulit untuk merekonstruksi ulang dengan curvelet. Intensitas energi dari noise acak yang tersebar pada penampang seismik menyebabkan melemahnya frekuensi yang baik sehingga saat rekonstruksi ulang, frekuensi tersebut hilang bersama dengan frekuensi noise . Kemudian, secara kuantitatif, berdasarkan gambar 4, grafik SNR restored terlihat semakin tinggi jika SNR noisy bernilai rendah. Gap (beda) antara nilai SNR noisy dan SNR restored menunjukkan bahwa kemampuan curvelet dalam merekonstruksi ulang gambar mampu meningkatkan SNR lebih tinggi daripada sebelumnya (data yang memiliki noise). Berdasarkan persamaan (1.6) didapatkan nilai SNR pada data noisy adalah antara 19 hingga $25 \mathrm{~dB}$ sedangkan pada data restored adalah antara 26 hingga $29 \mathrm{~dB}$.
Hasil transformasi curvelet menghasilkan perbedaan frekuensi data noisy dan data restored. Pada gambar 5, terlihat sangat signifikan bahwa noise acak dapat dihilangkan cukup baik. Perbedaan (pada bagian kanan) menunjukkan sangat banyak nosie yang telah dipetakan oleh curvelet sehingga pada data bagian tengah tidak memiliki sama sekali frekuensi noise acak.

\section{KESIMPULAN}

Berdasarkan hasil percobaan dan analis is data, maka dapat diberikan kesimpulan sebagai berikut :

1. Nilai SNR pada data seismik sintetik "Antiklin"yaitu antara 19-25 dB pada data noisy dan pada data curvelet memiliki nilai antara 27-29 dB.

2. Data dengan rekonstruksi terbaik adalah data pada percobaan pertama (gambar 3 bagian a1 dan a2).

\section{UCAPAN TERIMA KASIH}

Penulis mengucapkan terima kasih pada software lisensi Tesseral Pro, SeisLab 10.0301 dan algoritma pada proyek CURVELAB (www.curvelab.org) dalam memfasilitasi Studi penulis. Tanpa mereka tulisan ini tidak akan menjadi utuh dalam proses penulisannya.

\section{DAFTAR PUSTAKA}

[1] B. Kennet, Seismik Wave Propagation. Canberra: Cambridge University Press, 1983.

[2] L. Canales, "Random noise reduction," SEG Tech. Progr. Expand. Abstr., pp. 525-527, 1984.

[3] B. Milkereit, "Noise suppression and coherency," Stat. Appl. Earth Sci., pp. 243-248, 1990.

[4] R. Neelamani, "Coheren and Random Noise Attenuation Using Curvelet Trasnform," in SEG Leading Edge, 2008, pp. 240-248.

[5] E Candes, "Fast Discrete Curvelet Transform," Multiscale Model Simul, vol. 5, pp. 861-899, 2006.

[6] F. Herrmann, "Multiple prediction from incomplete data with the focused curvelet transform," in SEG/San Antonio 2007 Annual Meeting, 2007.

[7] J. Ma, "Curvelet Transform [A review recent Application," in IEEE, 2010.

[8] A. Gorszczyk, M. Malinowski, and G. Bellefleur, "Enhancing 3D post-stack seismik data acquired in hardrock environment using 2D curvelet transform," Geophys. Prospect., vol. 63, pp. 903-918, 2015. 